\title{
Minimum Atrial Rate by Electrocardiogram
}

National Cancer Institute

\section{Source}

National Cancer Institute. Minimum Atrial Rate by Electrocardiogram. NCI Thesaurus.

Code C119255.

An electrocardiographic measurement of the minimum rate of atrial depolarizations ( $P$ waves) recorded during a specified period of time, and usually expressed in beats per minute. 